Bangladesh J. Bot. 47(4): 953-959, 2018 (December)

\title{
ANTIOXIDANT POTENTIAL OF FIVE COMMERCIALLY LESS VALUED LEAFY VEGETABLES FROM BANGLADESH
}

\author{
Kishwar Jahan Shethi* and Mohammad Zashim Uddin \\ Department of Botany, University of Dhaka, Dhaka-1000, Bangladesh \\ Keywords: Antioxidant, Polyphenols, Flavonoids
}

\begin{abstract}
To evaluate the antioxidant potential of less valued green leafy vegetables of Bangladesh, the methanolic extracts of Alternanthera sessilis, A. philoxeroides, A. paronychioides, Glinus oppositifolius and Portulaca oleracea were subjected to assay for total phenolic content, total flavonoid content and DPPH free radicle scavenging activity. Among the studied materials, A. sessilis showed the highest phenolic and flavonoid content. However, G. oppositifolius presented the lowest phenolic content $(14.53 \pm 0.48 \mathrm{mg}$ of GAE/g of sample) and P. oleracea exhibited minimum (7.005 $\pm 0.25 \mathrm{mg}$ of RUE/g of sample) flavonoid content. DPPH radical scavenging activity was found to increase with increase in the concentration of each individual material. A. philoxiroides $\left(\mathrm{IC}_{50}=6.07 \pm 0.27 \mu \mathrm{g} / \mathrm{ml}\right.$ ) was found as the most active in DPPH radical percentage inhibition, which was followed by $A$. sessilis $\left(\mathrm{IC}_{50}=7.17 \pm 0.67 \mu \mathrm{g} / \mathrm{ml}\right.$ ). Interestingly, $A$. paronychioides, in spite of having good amount of total phenolic and flavonoid content, showed less DPPH scavenging activity. No linear relationship was found to exist in case of the total phenolic, flavonoid content and DPPH scavenging activity among $G$. oppositifolius, $P$. oleracea and A. paronychioides. The results from different methods may differ substantially because each complex chemical reaction generates unique values. However, all the five plants exhibited creditable antioxidant activity and thus consumption of these vegetables may play important role in combating oxidative stresses and thereby help in retaining good health.
\end{abstract}

\section{Introduction}

Free radicals are continuously produced in human body and they are important for the preservation of normal physiological functions (Singal and Krishenbaum 1990). Oxidative stress is a condition in which there is an accelerated production of reactive oxygen species (ROS) and reduced levels of antioxidant system resulting in cell damage leading to the pathogenesis of a variety of human diseases (Frei 1994). Though humans and other organisms have antioxidant defenses (enzymes, such as superoxide dismutase and catalase, or compounds such as ascorbic acid, tocopherols and glutathione) and repair systems that have evolved to guard them against oxidative damages, these systems are inadequate to totally defend the damage (Simic 1998, Mau et al. 2004). In present times, it is believed that the regular consumption of dietary antioxidants may reduce the risk of several serious diseases. Fruits and vegetables contain a wide variety of biologically active, non-nutritive compounds known as phytochemicals. These phytochemicals impart health benefits beyond basic nutrition. Moreover, WHO (2002) reported that $25 \%$ of herbal drugs in modern pharmacopeia are plant based and several synthetic drugs are manufactured by using chemical substances isolated from plants. In a developing country, like Bangladesh where about $80 \%$ of the people are from rural areas and dependent upon ethno botanical knowledge, the search for potential plant species and their proper validation for consumption are of great importance. Green leafy vegetables are rich sources of many nutrients and form a major category of vegetable groups that have been designated as 'nature's anti-aging wonders'. Diverse green leafy vegetables are consumed in different parts of Bangladesh of which some are common throughout the country and cultivated commercially (e.g. red amaranth, leaf amaranth, basella, spinach etc.). However, a number of other leafy vegetables are consumed by rural as well urban

*Author for correspondence: <kishwar.botany@du.ac.bd>. 
people which are commercially less valued in spite of their occurrence throughout the country. Ethno medicinal reports (Uddin et al. 2015) on such plants indicate their food value and accountability to commercialize those vegetables.

Although ethno botanical studies have been carrying out to document existing knowledge on plants from people in different districts of Bangladesh, fewer attempts have been initiated yet to validate that knowledge through in vitro analyses. During antioxidant activity study, Djordjevic et al. 2011 placed focus on determination of plant derived polyphenols because phenolic compounds act as radical scavengers, reducing agents and chelators of metal ions. According to Frankel 1995, flavonoids - a group of polyphenolic compounds with known properties, which include free radical scavenging, inhibition of hydrolytic and oxidative enzymes and antiinflammatory actions, might be considered as a part of antioxidant activity determination. The DPPH radical has been widely used to evaluate the free radicals scavenging ability of various natural products and has been accepted as a model compound for free radicals originating in lipids (Porto et al. 2000). Though several research works have been carried out on the antioxidant capacity of Alternanthera sessilis, A. philoxiroides, Glinus oppositifolius and Portulaca oleracea separately (Asok et al. 2009, Erkan 2012, Ho et al. 2012, Uddin et al. 2012, Chinmayee et al. 2013, Vasincu et al. 2014), no works have been reported on A. paronychioides so far. Besides, this is a first attempt to compare among five commercially under rated but common ethnic green vegetables from Bangladesh in regard to their potential antioxidant context. Therefore, the present work was designed to collect the above mentioned five samples from the study area and subjected to determine amount of total phenolic and flavonoid content and DPPH free radical scavenging activity.

\section{Materials and Methods}

Five trivialized species of leafy vegetables which are available throughout the country and occasionally sold in street markets of Dhaka city were selected for the biochemical analyses in order to determine their potential antioxidant activity. The species for the present study include Helencha (Alternanthera philoxeroides (Mart.) Griseb.), Sechi (A. sessilis (L.) R.Br. ex DC.), Putishak (A. paronychioides A. St. - Hil), Gima (Glinus oppositifolius (L.) Aug. DC.) and Nuinna (Portulaca oleracea L.) (Fig. 1). All the materials were collected form Abdullahpur, Keranigonj, Dhaka and authenticated by the taxonomists of Dhaka University Salar Khan Herbarium, Department of Botany, University of Dhaka. Except rotary evaporation which was conducted in Center for Advanced Research in Sciences (CARS), University of Dhaka all the experiments were carried out in the Plant Physiology, Nutrition and Plant Biochemistry Laboratory, Department of Botany, University of Dhaka.

Edible portion i.e. leaves were used for the experimental study (fresh weight $500 \mathrm{~g}$ for each material) and cleaned properly with distilled water, dried in room temperature (around $25^{\circ} \mathrm{C}$ ) under shed for 3 days and oven dried at $50^{\circ} \mathrm{C}$ for 3 days before powdered in a grinder machine. The scientific names, local names, English names, family names, parts used and voucher specimen numbers are presented in Table 1. Powdered plant materials were kept in air tight container in dark and cool place.

About $25 \mathrm{~g}$ of powdered sample from each plant material was extracted with $300 \mathrm{ml}$ of $99 \%$ methanol in an orbital shaker at $180 \mathrm{rpm}$ for $48 \mathrm{hrs}$ at $25^{\circ} \mathrm{C}$. The extracts were filtered using Rotilabo®- round filters, type 601A $(125 \mathrm{~mm})$ and concentrated in a rotary evaporator at around $40^{\circ} \mathrm{C}$. Per cent recovery of the concentrated extracts of 5 plant materials was calculated as follows and shown in Table 2. 
$\%$ recovery $=\frac{\text { Amount of product recovered }(\mathrm{g})}{\text { Amount of crude material used }(\mathrm{g})} \times 100$

Concentrated extracts were stored at $4^{\circ} \mathrm{C}$ for further analysis.

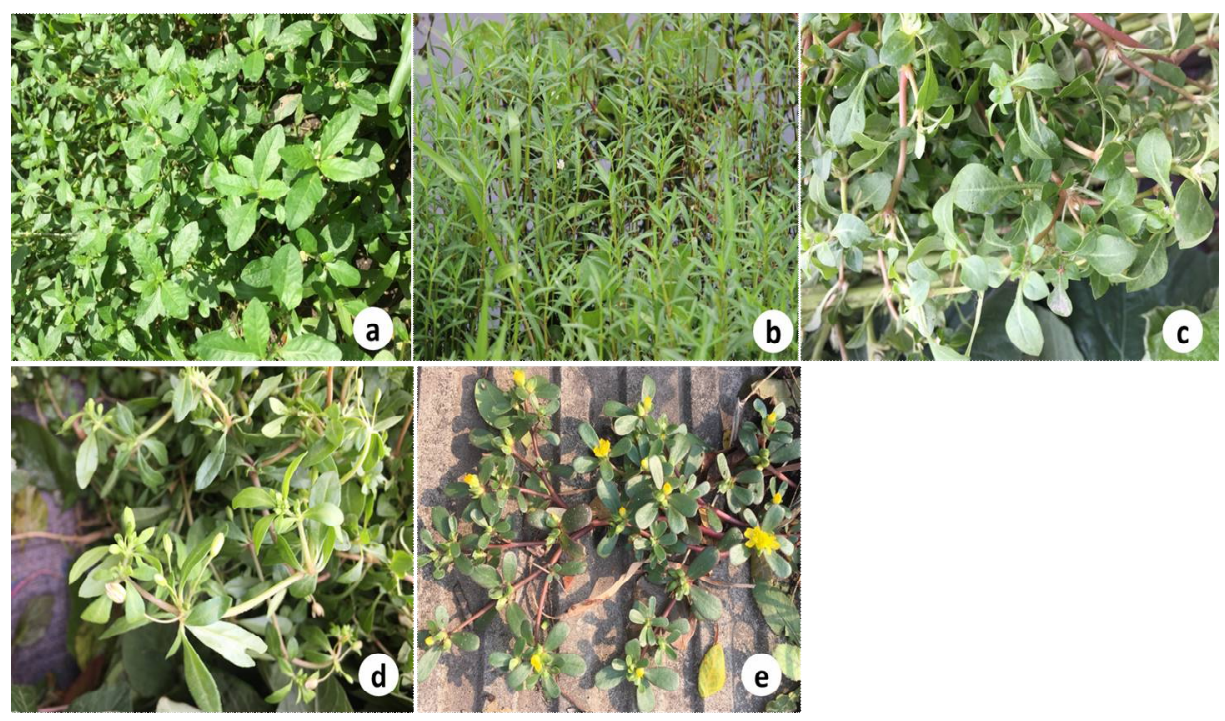

Fig. 1. Fresh samples of five studied leafy vegetables namely, (a) Alternathera sessilis, (b) A. philoxeroides, (c) A. paronychioides, (d) Glinus oppositifolius and (e) Portulaca oleracea.

Table 1. Description on studied plant materials.

\begin{tabular}{lllccc}
\hline $\begin{array}{l}\text { Local } \\
\text { name }\end{array}$ & $\begin{array}{l}\text { English } \\
\text { name }\end{array}$ & $\begin{array}{l}\text { Scientific } \\
\text { name }\end{array}$ & Family & $\begin{array}{c}\text { Parts } \\
\text { used }\end{array}$ & $\begin{array}{c}\text { Voucher specimen } \\
\text { number }\end{array}$ \\
\hline Sechi & Sessile joyweed & Alternanthera sessilis & Amaranthaceae & Leaves & DUSH10803 \\
Helencha & Alligator weed & A. philoxeroides & $n$ & $"$ & DUSH10800 \\
Putishak & Smooth chaff-flower & A. paronychioides & $"$ & $"$ & DUSH10799 \\
Gima & Indian chickweed & Glinus oppositifolius & Molluginaceae & $"$ & DUSH10798 \\
Nuinna & Purslane & Portulaca oleracea & Portulacaceae & $"$ & DUSH10801 \\
\hline
\end{tabular}

The content of total phenol in different samples was determined spectrophotometrically using Folin-Ciocalteu reagent (McDonald et al. 2001) with slight modifications. The total phenolic content (TPC) was determined in comparison with standard gallic acid and the results were expressed in terms of $\mathrm{mg}$ gallic acid equivalent $(\mathrm{GAE} / \mathrm{g})$ of sample extract using the following formula:

$$
\mathrm{T}=(\mathrm{C} \times \mathrm{V}) / \mathrm{M}
$$

Where, $\mathrm{T}=$ Total content of phenolic compounds ( $\mathrm{mg}$ of GAE/g sample), $\mathrm{C}=$ Concentration of gallic acid established from the calibration curve $(\mathrm{mg} / \mathrm{ml}), \mathrm{V}=$ Volume of extract $(\mathrm{ml}), \mathrm{M}=$ Weight of methanolic plant extract $(\mathrm{g})$. The absorbance was recorded at $765 \mathrm{~nm}$. 
Total flavonoid content was estimated by aluminum chloride colorimetric method developed by Cheng et al. (2003). Total flavonoid content (TFC) in the plant extracts was actuated by the following formula and using rutin hydrate as standard. Absorbance was measured at $415 \mathrm{~nm}$ and the results were expressed in terms of rutin hydrate equivalents (mg of RUE/g sample).

$\mathrm{T}=(\mathrm{C} \times \mathrm{V}) / \mathrm{M}$

Where, $\mathrm{T}=$ Total content of flavonoid compounds ( $\mathrm{mg}$ of RUE/g sample), $\mathrm{C}=$ Concentration of rutin hydrate established from the calibration curve $(\mathrm{mg} / \mathrm{ml}), \mathrm{V}=$ Volume of extract $(\mathrm{ml}), \mathrm{M}=$ Weight of methanolic plant extract $(\mathrm{g})$.

The DPPH assay was performed as described by Blois (1998) with minor modifications. In brief, $0.1 \mathrm{mM}$ solution of DPPH in methanol was prepared. This solution $(1 \mathrm{ml})$ was added to $2 \mathrm{ml}$ of different extracts in methanol at different concentration $(3,6,12.5,25,50,100 \mu \mathrm{g} / \mathrm{ml})$ which were prepared by dilution method. The solution was shaken well and incubated in the dark for 30 min at room temperature. The absorbance was subsequently recorded at $517 \mathrm{~nm}$. The scavenging activity was estimated based on the percentage of DPPH radical scavenged using the following equation (Achola and Muenge 1998):

DPPH scavenging effect $(\%)$ or Per cent inhibition $=\mathrm{A}_{0}-\mathrm{A}_{1} / \mathrm{A}_{0} \times 100$

Where, $A_{0}$ was the absorbance of control reaction and $A_{1}$ was the absorbance in presence of test or standard sample. For control $1 \mathrm{ml}$ of methanol in place of the sample extract along with DPPH was used. During DPPH assay reference standard compound being used was ascorbic acid. Inhibition capacity at $50 \%\left(\mathrm{IC}_{50}\right)$, a measure of the extract concentration which is required for $50 \%$ inhibition of the free radical DPPH, was determined. The $\mathrm{IC}_{50}$ value was calculated from linear regression equation by plotting the studied concentrations against percentage of DPPH scavenging activity.

To record absorbance at different wavelengths Shimadzu UV-1800 spectrophotometer was utilized and all tests were performed in triplicate.

\section{Results and Discussion}

Phenolic compounds are extensively distributed in plants that have gained great attention due to their antioxidant activities and free radical-scavenging abilities, which potentially have beneficial implications for human health (Govindarajan et al. 2007). Methanol has been reported to be the most suitable solvent in the extraction of polyphenolic compounds from plant tissue due to its ability to inhibit the action of polyphenol oxidase that causes the oxidation of polyphenols and its ease of evaporation compared to water (Anokwuru et al. 2011). The total phenol content of the methanolic extract of studied 5 plant materials in terms of gallic acid equivalent was between $37.28 \mathrm{mg} \mathrm{GAE} / \mathrm{g}$ of sample and $14.53 \mathrm{mg} \mathrm{GAE} / \mathrm{g}$ of sample (the standard curve equation $\mathrm{y}=$ $\left.0.011 \times-0.886, \mathrm{r}^{2}=0.856\right)$. The total phenolic content was observed in 5 plants extract as: $A$. sessilis $>$ A. paronychioides $>$ A. philoxiroides $>$ P.oleracea $>$ G. oppositifolius (Table 2).

From the work of Hou et al. 2003 it is known that, flavonoids with a certain structure and particularly hydroxyl group in the molecule can act as proton donators and show radical scavenging activity. Total flavonoid content (TFC) from methanolic extracts of 5 different plant materials was estimated in terms of rutin hydrate equivalent (RUE)/g of sample extract (standard curve equation $\left.\mathrm{y}=0.002 \mathrm{x}+0.009, \mathrm{r}^{2}=0.995\right)$ and ranged between $36.75 \mathrm{mg}$ RUE/g of sample and $7.005 \mathrm{mg} \mathrm{RUE} / \mathrm{g}$ of sample (Table 1). Similar to TPC, total flavonoid content was also the highest in A. sessilis. The total flavonoid content was observed in 5 plants extract as: A. sessilis > A. philoxiroides $>$ A. paronychioides $>$ G. oppositifolius $>$ P. oleracea $($ Table 2). 
Table 2. Per cent recovery, total phenolic content and total flavonoid content of plant methanolic extracts.

\begin{tabular}{lccc}
\hline Scientific name & $\begin{array}{l}\text { \% recovery } \\
\text { of extracts }\end{array}$ & $\begin{array}{l}\text { Total phenolic content } \\
\text { (mg of GAE/g of sample) }\end{array}$ & $\begin{array}{l}\text { Total flavonoid content } \\
\text { (mg of RUE/g of sample) }\end{array}$ \\
\hline Alternanthera sessilis & 4 & $37.28 \pm 0.25$ & $36.75 \pm 0.32$ \\
A. philoxeroides & 8 & $21.61 \pm 0.58$ & $26.56 \pm 0.45$ \\
A. paronychioides & 6 & $22.40 \pm 0.45$ & $21.23 \pm 0.27$ \\
Glinus oppositifolius & 10 & $14.53 \pm 0.48$ & $12.21 \pm 0.22$ \\
Portulaca oleracea & 8 & $18.93 \pm 0.32$ & $7.005 \pm 0.23$ \\
\hline
\end{tabular}

Results are the average of triplicate measurements \pm standard deviation.

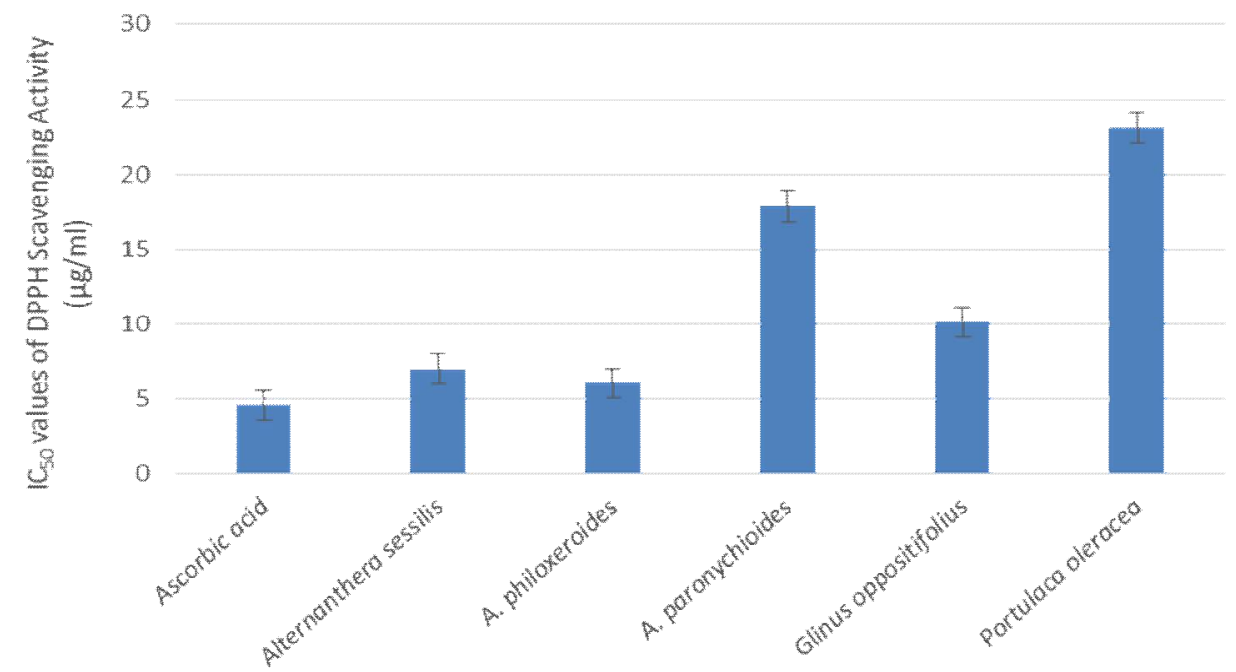

Fig. 2. DPPH radical scavenging activity of studied plant species. Lower $\mathrm{IC}_{50}$ value indicates higher antioxidant activity. Values are mean of three replicate determinations $(n=3) \pm$ standard deviation.

Brand-Williams et al. (1995) demonstrated that the reducing ability of antioxidants towards DPPH was evaluated by monitoring the absorbance at $517 \mathrm{~nm}$ against various concentrations of sample extract. It means methanolic extract of plant at higher concentrations captured more free radicals formed by DPPH resulting into decrease in absorbance and increase in percentage of DPPH scavenging effect. DPPH radical scavenging activity of the plant extracts at varying concentrations $(3-100 \mu \mathrm{g} / \mathrm{ml}$ ) was measured during the experiment. All the materials showed appreciable free radical scavenging activities. A dose-response relationship was found in the DPPH radical scavenging activity; the activity increased with an increase in the concentration of each individual material. The lower the $\mathrm{IC}_{50}$ value the higher in antioxidant capacity and therefore A. philoxiroides $\left(\mathrm{IC}_{50}=6.07 \pm 0.27 \mu \mathrm{g} / \mathrm{ml}\right)$ was the most active in percentage inhibition which was followed by $A$. sessilis $\left(\mathrm{IC}_{50}=7.17 \pm 0.67 \mu \mathrm{g} / \mathrm{ml}\right.$ ) (Fig. 2). Both A. philoxiroides and A. sessilis contained high amount of TPC and TFC which was in accordance with their higher DPPH scavenging activity. On the contrary, A. paronychioides in spite of demonstrating good amount of 
TPC and TFC was found to show less DPPH scavenging activity. No linear relationship exists in case of the total phenolic, flavonoid content and DPPH scavenging activity among $G$. oppositifolius, P. oleracea and A. paronychioides. Shethi 2017 has also reported similar trend in case of antioxidant potentiality from studying several consumable aromatic herbs of Bangladesh. Reason might be explained by different researchers (Javanmardia et al. 2003, Bajpai et al. 2005 and Sengul et al. 2009) as the antioxidant activity observed was not solely from the phenolic and flavonoid content, might also come from the presence of other antioxidant secondary metabolites, such as volatile oils, carotenoids and vitamins as well as the synergistic effects among them which also contribute to the total antioxidant capacity. However, Siatka and Kasparova (2010) showed that, difference in the value of polyphenols from reported articles might be due to the difference in the harvesting season and geographical location in which the plant grown as flavonoid content is influenced by multi factorial influence of the environment. Like flavonoids, phenolic levels could also be affected by temperature and other stresses apart from post-harvest handling and storage conditions. Also, the accumulation of phenolics depends on the genetic and environmental factors; hence it may vary between the species and even between the cultivars (Gawlik-Dziki 2008). Moreover, the values indicating antioxidant potentials might vary across different research works since different standard compounds have been used for analysis in reported works.

Present study evaluated antioxidant potential of 5 commonly consumed but under rated leafy vegetables of Bangladesh following TPC, TFC and DPPH radical scavenging activity. Among the studied materials A. sessilis showed the highest TPC and TFC though placed second highest regarding percentage DPPH scavenging activity after $A$. philoxiroides. Lowest $\mathrm{IC}_{50}$ value obtained in A. philoxiroides represent the most antioxidant potentiality. However, all the five plants exhibited commendable antioxidant activity and thus consumption of these vegetables may play a role in preventing human disease in which free radicals are involved, such as cancer, cardiovascular diseases and aging. Nevertheless, further investigations on individual components, in vivo antioxidant activity, and the different antioxidant mechanisms for the studied species require to be justified.

\section{Acknowledgements}

The authors acknowledge the financial support from Ministry of Science and Technology, Government of the People's Republic of Bangladesh through Special Allocation for "Science and Technology Projects".

\section{References}

Achola KJ and Muenge RW 1998. Bronchodilating and uterine activities of Ageratum conyzoides extract. Pharm. Biol. 36(2): 93-96.

Anokwuru CP, Ijeoma E, Olusola A and Ayobami OA 2011. Polyphenol content and antioxidant activity of Hibiscus sabdariffa calyx. Res. J. Med. Plant 5: 557-566.

Asok Kumar K, Uma Maheswari M, Sivashanmugam AT, Subhadra Devi V, Subhashini N and Ravi TK 2009. Free radical scavenging and antioxidant activities of Glinus oppositifolius (carpet weed) using different in vitro assay systems. Pharm. Biol. 47(6): 474-482.

Bajpai M, Pande A, Tewari SK and Prakash D 2005. Phenolic contents and antioxidant activity of some food and medicinal plants. Int. J. of Food Sci. and Nutri. 56(4): 287-291.

Blois MS 1998. Antioxidant determinations by the use of a stable free radical. Nature 26: 1199-1200.

Brand-Williams W, Cuvelier ME and Berset C 1995. Use of a free radical method to evaluate antioxidant activity. Lebensm.-Wiss. u.-Technol. 28: 25-30.

Cheng HY, Lin TC, Yu KH, Yang CM and Lin CC 2003. Antioxidant and Free Radical Scavenging Activities of Terminalia chebula. Biol. Pharm. Bull. 26(9): 1331-1335. 
Chinmayee MD, Stephan P, Anu MS, Sheeba AM, Mini I and Swapna TS 2013. Cadmium stress on antioxidant activity of two Alternanthera sp. J. of Sci. and Ind. Res. 72: 558-562.

Djordjevic MT, Siler-Marinkovic SS and Dimitrijevei-Brankovic IS 2011. Antioxidant activity and total phenolic content in some cereals and legumes. Int. J. Food Prop. 14: 175-184.

Erkan N 2012. Antioxidant activity and phenolic compounds of fractions from Portulaca oleracea L. Food Chem. 133(9): 775-781.

Frankel E 1995. Nutritional benefits of flavonoids. In: Chemistry and Cancer Prevention. (Abstract); C6-2. Int. Conf. on food factors. Hamamatsu, Japan.

Frei B 1994. Reactive oxygen species and antioxidant vitamins: Mechanism of action. Ame. J. Med. 97(3A): 15-23.

Gawlik-Dziki U 2008. Effect of hydrothermal treatment on the antioxidant properties of broccoli (Brassica oleracea var. botrytis italica) florets. Food Chem. 109: 393-401.

Govindarajan R, Singh DP and Rawat AKS 2007. High-performance liquid chromatographic method for the quantification of phenolics in 'Chyavanprash' a potent Ayurvedic drug. J. Pharm. Biomed. Anal. 43: 527-532.

Ho YL, Huang SS, Deng JS, Lin YH, Chang YS and Huang GJ 2012. In vitro antioxidant properties and total phenolic contents of wetland medicinal plants in Taiwan. Bot. Studies. 3: 55-66.

Hou WC, Lin RD, Cheng KT, Hung YT, Cho CH, Chen CH, Hwang SY and Lee MH 2003. Free radical scavenging activity of Taiwanese native plants. Phytomedicine 10(2-3): 170-175.

Javanmardia J, Stushnoffb BC, Lockeb E and Vivancob JM 2003. Antioxidant activity and total phenolic content of Iranian Ocimum accessions. Food Chem. 83: 47-50.

Mau JL, Chang CN, Huang SJ and Chen CC 2004. Antioxidant properties of methanolic extracts from Grifola frondosa, Morchella esculenta and Termitomyces albuminosus mycelia. Food Chem. 87: 11-18.

McDonald S, Prenzler PD, Antolovich M and Robards K 2001. Phenolic content and antioxidant activity of olive extracts. Food Chem.73: 3-84.

Porto CD, Calligaris S, Cellotti E and Nicoli MC 2000. Antiradical properties of commercial cognacs assessed by the DPPH test. J. Agric. Food Chem. 48: 4241-245.

Sengul M, Yildiz H, Gungor N, Cetin B, Eser Z and Ercisli S 2009. Total phenolic content, antioxidant and antimicrobial activities of some medicinal plants. Pak J. Pharm. Sci. 22(1): 102-106.

Shethi KJ 2017. Evaluation of Antioxidant Activity of Four Locally Grown Aromatic Herbs Commonly Consumed in Bangladesh. Biores. Comm. 3(2): 391-396.

Siatka T and Kasparova M 2010. Seasonal variation in total phenolic and flavonoid contents and DPPH scavenging activity of Bellis perennis L. flowers. Molecules 15(12): 9450-9461.

Simic MG 1998. Mechanisms of inhibition of free-radical processed in mutagenesis and carcinogenesis. Mutat. Res. 202:377-86.

Singal PK and Kirshenbaum LA 1990. A relative deficit in antioxidant reserve may contribute in cardiac failure. Can. J. Cardiol. 6(2): 47-9.

Uddin MK, Juraimi AS, Ali ME and Ismail MR 2012. Evaluation of Antioxidant Properties and Mineral Composition of Purslane (Portulaca oleracea L.) at Different Growth Stages. Int. J. Mol. Sci. 13(8): 10257-10267.

Uddin MZ, Kibria MG and Hassan MA 2015. Study of ethnomedicinal plants used by the local people of Feni district, Bangladesh. J. Asiat. Soc. Bangladesh, Sci. 41(2): 203-223.

Vasincu Al, Paulsen BS, Diallo D, Bild V and Miron A 2014. Antioxidant activities and phenolic contents of extracts from Glinus oppositifolius aerial parts. Rev. Med. Chir. Soc. Med. Nat. Iasi. 118(2): 564-570.

WHO 2002. Traditional Medicinen and Alternative Medicines. Geneva; Fact Sheet. No. 271. 